\title{
Agency Design and State Administrators: Political Insulation and Managers' Views of Their Workplace
}

Jennifer Symonds Morrison

Murray State University, jmorrison5@murraystate.edu

James C. Clinger

Murray State University

Follow this and additional works at: https://digitalcommons.murraystate.edu/faculty

Part of the Political Science Commons

(c) (7) (8)

This work is licensed under a Creative Commons Attribution-Noncommercial 4.0 License

\section{Recommended Citation}

Morrison, J. S., \& Clinger, J. C. (2021). Agency Design and State Administrators: Political Insulation and Managers' Views of Their Workplace. International Journal of Public Administration, 44(7), 557-563.

This Peer Reviewed/Refereed Publication is brought to you for free and open access by Murray State's Digital Commons. It has been accepted for inclusion in Faculty \& Staff Research and Creative Activity by an authorized administrator of Murray State's Digital Commons. For more information, please contact msu.digitalcommons@murraystate.edu. 


\title{
Agency Design and State Administrators: \\ Political Insulation and Managers' Views of Their Workplace
}

\author{
Dr. Jennifer Symonds Morrison \\ Murray State University \\ jmorrison5@murraystate.edu \\ and \\ Dr. James C. Clinger \\ Murray State University \\ jclinger@murraystate.edu
}

Paper presented at the annual meeting of the Kentucky Political Science Association in Danville, KY, March 2017. The authors wish to thank Stephen Agada and Maftuna Tojiboeva for their research assistance. Each author believes that any errors in the paper are the responsibility of his or her co-author. 


\begin{abstract}
This paper examines the impact of agency design upon the perceived workplace conditions within state agencies. Our research examines whether insulating features of agency structure such as independent commission status, removal of officers only for cause, and fixed terms for agency leaders are associated with perceptions by state agency managers that their work processes and environments are free of micromanagement and interference from political actors. Our data are drawn from the National Administrative Studies Project III, with additional information collected from state agency web sites and statutes. We largely find that administrators working within agencies headed by officials with fixed terms of service believe that top management trusts employees much more than do employees in other agencies. They also have much more pride in the agencies in which they work. We also find that agencies having a commission structure have managers that are perceived to be willing to take risks.
\end{abstract}

Key Words: agency design, political insulation, state agencies 


\section{Agency Design and State Administrators: \\ Political Insulation and Managers' Views of Their Workplace}

Public agencies in the United States demonstrate a wide variety of structural design characteristics, with some following a monocratic, Weberian bureaucratic pattern while others display a more decentralized, less formalized structure. Some are set up to be responsive to political superiors, while others are deliberately designed to be insulated in some fashion from outside forces, whether they be clientele groups, regulated interests, or politicians themselves. These various design features are often subject to debate and controversy at the time that the agencies are created. Some observers, such as Terry Moe (1989), have said that these bureaucracies are not designed to be effective. Instead, they represent the product of bargaining and in-fighting between different interests within a policymaking body. Some interests may demand some concessions with respect to the design of the agencies in return for supporting particular policies that the agency will carry out. As a result, the agencies' structures are a bundle of compromises that may help or hinder policy implementation.

Whatever the impact on policy, agency design may have implications for how government bureaucrats do their jobs and what experiences they have within their workplaces. Structural features that may appear hierarchical and efficient in a Weberian sense may make the bureaucratic workplace subject to the whims of a politically appointed agency head or prone to capture by regulated interests. An agency that is headed by a board or commission with fixed, staggered terms might be somewhat insulated from the petty tyrannies of one agency head, but might still lack direction as the plural leadership of the agency squabbles among itself or fails to maintain organizational discipline. 
Extant research is largely silent on how public administrators view their workplaces within agencies of different organizational structure. While there is a large literature on job satisfaction and organizational commitment among bureaucrats, there is next to nothing written on how design attributes affect their experiences and assessments of their agencies. Satisfaction and commitment are often treated as a function of particular HR policies, family-friendly practices, pay scales, or public service motivation. This study is intended to fill this void. The research reported here examines how aspects of the political insulation of state agencies affects how public managers, technicians, and professionals view their organization and immediate workplace. Specifically, we examine whether working in an agency headed by a board or commission, independent of other agencies, with leadership holding fixed terms, has any impact on what these bureaucrats think about their agencies. Much of the extant literature on public agencies presumes that administrators desire and seek autonomy and an enhanced reputation for their organizations (see Carpenter, 2010; Carpenter and Krause, 2012). If attributes of an agency structure promote the autonomy and reputation of an agency, they may impact the perceptions that public employees have of their workplaces. We examine the impact these attributes have on reported trust in agency leadership, pride in the organization, belief in the high ethical standards of agency management, and the willingness of managers and employees to take risk. We conduct this analysis using survey responses from the National Administrative Studies Project III: A Survey of Managers in Public and Non-Profit Organizations in Georgia and Illinois (NASP-III).

The paper proceeds as follows: The first section reviews the literature on efforts to insulate bureaucratic agencies through institutional design. These efforts were largely intended to prevent "capture" by clientele groups impacted by the actions of the agencies but were also 
sometimes intended to limit the role of political patronage and diminish the micromanagement of public organizations by politicians. The literature on political insulation is briefly compared to the research on job satisfaction and organizational commitment. The next section describes the analysis of the NASP-III data to determine the impact that structure may have upon the assessments of the respondents' agencies with respect to the level of trust within the agency, the pride they have in their organization, the ethical standards in their unit, and the degree to which agency personnel are afraid to take risks. The results of this analysis are reported in the following section. The paper concludes with some discussion of the implications of this analysis and some suggestions regarding what future research could contribute to this topic.

\section{Agency Design and the Public Workplace}

The rise of independent agencies with a plural leadership in the form of a board or commission became popular in the late nineteenth and early twentieth centuries, particularly in agencies that performed regulatory and licensing functions. State utility commissions, occupational licensing boards, civil service commissions all frequently took this organizational form. In many cases, the boards and commissions had members who were appointed by an executive to serve fixed and often staggered terms. Once appointed (often with legislative confirmation), board members could be removed only for cause. Sometimes these agency board members had to hold certain professional or occupational credentials and sometimes the enabling statutes required that the board composition reflect some sort of partisan balance. This kind of bureaucratic structure was often advocated by members of the Progressive movement, who felt that this kind of institutional design discourages patronage appointment and limited the influence of political actors. Arguably, this structure can protect bureaucratic discretion and insulating 
agency experts from intervention by politicians. The structure provides a credible commitment that the politicians' hands are at least somewhat tied when they try to interfere in agency operations (Miller and Whitford, 2016; Lewis, 2007).

In practice, however, it is not clear that this form of organization has insulated agencies form political influence as much as proponents desired (Carpenter and Moss, 2014). Some of the agencies, such as the Interstate Commerce Commission that were often regarded as "captured" by regulated interests had a commission structure. In any case, the effect that the structure has upon day-to-day activities in the agency workplace have not really been examined. Any impact on employee attitudes has largely been ignored. This research hopes to fill this void.

While agency structure has not been used as an explanatory variable in determining employee attitudes and assessments, other variables have been documented as causal factors affecting these outcomes. Research on trust and the public sector tends to focus on whether or not the public has trust in the government (Kim, 2005). Carnevale and Wechsler (1992), however, developed and tested a model of trust formation in public organizations, and found that trust in organizations related to work-attitudes with the most important determinants are established through the supervisors' attitudes in the work environment. Nyhan (2000) viewed trust "from an internal organizational and an external environmental perspective" (p. 88). Where most research focuses on external relationships (Downs, 1967; Gamson, 1968; Rockmon, 1981; Wildavsky, 1980) or the trust relationship between the public and public institutions (Berman, 1997; Carnevale, 1995; Marlow, Nyhan, Arrington, \& Pammer, 1994; Osborne \& Gaebler, 1992; Thomas, 1998), this research, which used data from a municipal government, concentrated on the interpersonal relationship between supervisor and subordinate, which can affect behaviors in organizations. The research found that by empowering employees and allowing them to 
participate in the decision-making process, trust increases. With 2003 survey data from the Georgia Department of Transportation, Feeney and Smith (2008) looked at the role of social embeddedness in the perceptions of public managers on contractors. While the results determined that managerial perceptions could be shaped to improve working relationships, this research was not conducted between supervisor and subordinate, nor was it conducted in the public sector.

While research can be found on trust within public agencies, studies of pride are rarely found. Zegans (1992) held focus-group discussions with nine career civil servants from state or local government on innovation in public agencies. In response to the question, "What motivates bureaucrats to innovate?" (Zegans, 1992, 146), there was discussion on whether "pride of ownership" was important. The group agreed that pride in work is important, but not pride as far as taking credit for work. In reducing a million articles on organizational change to eight factors, Fernandez and Rainey (2006) found pride was created in the organization's history and success by building internal support and overcoming resistance to change. In a study of private-sector consumer complaint workers, Jin and Guy (2009) found several predictors of "feelings about the level of work pride" (p. 98). The same variables that impacted job satisfaction (effects of personal efficacy and emotion work), as well as being able to express different emotions, had a positive effect on worker pride. Feeney and Boardman (2011) used the same National Administration Studies Project III data as is used in this study in order "to understand what individual-level characteristics correlate with highly positive worker perceptions of attitudes towards government organizations" (p. 674), so that public organizations could "populate their ranks with workers who harbor highly positive attitudes towards and perceptions of their organizations" (p. 688). Both pride and high ethical standards were included in their definition 
of organizational confidence. Nevertheless, the literature does not examine how the structures of an organization can affect employees' sense of pride in the agency.

Woodrow Wilson expected that public administrators would display high ethical standards; however, this is not always so. Burke and Black (1990), Bruce (1994), Menzel (1992, 1993a, 1993b, 1995, 1996b), in research on state and local governments, found that: 1) managers and supervisors influence the ethics of employees, and therefore, on organizational performance; and 2) the ethical climate of an organization has a positive effect on an organization's performance. Fattah (2011) questioned what is going right in the United States as, based on the number of public employees, corruption and unethical behaviors are essentially kept in check, and the US is considered one of the least corrupt systems in the world. Hassan, Wright, and Yukl (2014) explored the consequences of ethical leadership and found that ethical leadership did reduce absenteeism, as it had a positive influence on organization commitment.

Risk culture, as defined by Bozeman and Kingsley (1998), is “the organization's propensity to take risks as perceived by the managers in the organization" (p. 111); however, they argue that perceptions define the culture, as opposed to "any tangible and documented set of decisions or actions taken by organizational actors" (p. 111). Baird and Thomas (1985) investigated the impact of particular variables on the tendency to take strategic risks, finding that while individuals deciding to take risks is complex, it is even more complex for organizations to formulate and realize risky strategies. Clark (2016) agreed with Bellante and Link (1981), Chen and Bozeman (2012), and Dong (2014), that risk aversion in the public sector is a result of the organizational environment; and Eckard (2014) that the reason the public sector is less averse is their commitment to accountability. Notably, the prior research on trust, pride in the organization, risk culture, and ethical standards has not focused on agency structure as a 
determinant of employee behavior or attitudes. The results of the analysis are reported in Tables 2 and 3.

\section{Data and Methods}

Data for this analysis comes primarily from the National Administrative Studies Project (NASP-III), a project initiated by Barry Bozeman and continued by Bozeman and his collaborators. These data are drawn from responses to a mail survey to a random sample of state-level public managers, upper-level professionals, and technicians in Georgia and Illinois. The questionnaire includes a number of demographic, attitudinal, and motivational questions, but also asks respondents to identify the organization in which they work. Our analysis is limited to state government agency personnel, although there are some non-profit managers in the original sample. After identifying the agencies of the respondents, the authors' graduate assistants visited the state web pages to collect data on agency design characteristics. The graduate assistants coded agencies with respect to whether they were headed by a single director or by a board or commission, with respect to whether they were employed in an independent agency or one situated within another organization, whether the agency leadership served fixed or indefinite terms and the length of the terms that were served. The coding scheme followed that used by David E. Lewis in his study of federal agency design (2003). The presence of a design attribute was coded as " 1 " while its absence was coded as " 0 ". The length of terms was coded as " 0 " if there were no fixed terms, and as the number of years of term length otherwise.

The first dependent variable estimated was the response to a survey item indicating "Top management displays a high level of trust in this organization's employees." High scores indicated high trust with low scores indicating low trust. The second dependent variable 
examined was the response to a survey item indicating, "I feel a sense of pride working for this organization." The third variable estimated was the response to a survey item indicating "This organization has high ethical standards." We also estimated three measures representing the fear of taking risks. The first of these was the response to survey items indicating that employees were afraid of taking risks. The second indicated that managers were afraid to take risks. The last was a measure we call "risk culture," which is simply the sum of the two previously described measures. The values for these dependent variables are estimated in models including variables representing the agency design characteristics. The design characteristics used here are the presence of a commission form of organization, independent agency status, fixed terms for agency leadership, and length of terms for agency leaders. We also employed some basic control variables, such as respondent age, whether the respondent was female, the full-time-equivalent number of employees of the agency (FTE) as a measure of size, and whether the respondent worked in a Georgia or Illinois state agency. Because the values for the FTE of agencies include a number of outliers that might skew the results, the values were converted to natural log of the original values. The estimates from models using logged values for FTE are not substantially different from the results of analyses using non-transformed FTE, so the latter results are reported in this paper. The descriptive statistics for these variables are listed in Table 1.

\section{[Insert Table 1 Here]}

The analysis is conducted using ordinary least squares estimates of the responses to a variety of survey questions, measured using a Likert scale. Other background variables for the respondent and his/her agency were used in some preliminary models, but those results are not reported here. 


\section{Results}

The level of explained variance in these models is relatively low, but the models as a whole are still statistically significant. Of the theoretically interesting agency design variables, the presence of fixed terms seems to be positively and significantly related to trust and pride in the organization. An examination of standardized coefficients reveals that fixed terms are the best predictor of trust values of any variable in the model. Term length, somewhat surprisingly, is negatively and significantly related to those same variables. Whether the agency is run by a commission and whether it is independent of a larger bureaucracy seems to make no substantial difference with regard to manager's attitudes. Working in a Georgia, rather than an Illinois, state agency seems related to trust, pride, and high ethical standards. Older employees seem to have more pride in their agencies and perceive that the ethical standards in their agencies are higher. None of the structural variables have statistically significant impacts upon perceptions of ethical standards

With respect to the fear of risk, both the commission organization form and the presence of fixed terms for agency leaders seem to diminish fear of taking risks on the part of employees, managers, or both. Again, we see a counterintuitive finding with respect to the length of terms. This variable seems positively related to fear of risk in all three models. Women express less fear of risk-taking in their organizations, as do older employees and the respondents in Georgia. Size, represented by FTE, seems unrelated to fear of risk, although it appears to be related consistently and negatively to trust, pride, and ethical standards.

\section{Discussion}


From this analysis, we can make a few basic conclusions. First of all, size matters. The larger agencies in terms of FTE seem to display much less trust, much less pride, and lower ethical standards. However, size does not appear to have much impact upon fear of taking risks. Exactly why size matters is not obvious. Prior research in organizational sociology (e.g., Blau and Schoenherr, 1971) has found that larger organizations tend to be more hierarchical, rulebound, and formalized. Perhaps those characteristics are related to trust, pride, and ethical standards. Perhaps smaller organizations are simply friendlier, more personal places in which to work, which engenders positive feelings toward the agency. In any event, these results may give one pause when pondering the benefits of consolidating multiple agencies into larger departments.

Our results also indicate, as any good realtor knows, that location matters, too. The respondents from the Georgia state agencies were generally much happier with their workplaces than were the respondents from Illinois. It is not clear whether we should regard this as high praise for Georgia or just an acknowledgment that state government in Illinois is deeply troubled. We should acknowledge that the survey from which data were drawn for this analysis had Governor Rod Blagojevich in office while the respondents filled out their questionnaires. Perhaps now that Governor Blagojevich is a guest of the taxpayers in federal prison, Illinois state employees will have a higher view of their workplaces. In light of the fiscal problems and the budget stalemate facing that state, we rather doubt that their assessments would be wholly positive.

Demographic characteristics of bureaucrats may make a bit of difference, too. Older employees seem to have much more trust in their agency leaders, more pride in their agencies, more belief in the ethical standards of their organizations, and much more confidence that their 
fellow employees and their managers are willing to accept risk. We do not know if this represents a cohort effect or a simple life cycle effect, but it does indicate that older employees see their workplaces differently from their younger colleagues. Gender also seems to matter. Despite reports of sexual harassment and glass ceilings, the women in this sample tend to view their workplaces somewhat more favorably than do men. Female respondents seem to have a bit more pride in their agencies than do men. Women also perceive that employees in their agencies are less likely to fear taking risks.

The primary variables of theoretical interest motivating this study were agency design characteristics. These findings are a bit more complicated than expected. The commission form of agency design is not related significantly to trust, pride, or perceived ethical standards. However, it is significantly related to beliefs that managers are afraid to take risks. An even stronger result can be found for the presence of fixed terms for agency leaders. This variable is positively associated with trust and pride, as well as negatively related to perceptions that employees are afraid to take risks. The commission format and the presence of fixed terms (which is generally found with the commission format) may provide the security and sense of autonomy that administrators and middle managers crave. Ironically, the longer leaders' terms are, the lower the pride and trust, and the more likely respondents were to believe that employees are willing and able to accept risks. We do not have a good explanation for this result. Perhaps a few outlier respondents from agencies with leaders with long fixed terms are affecting this outcome. It could also be the case that when agency leaders serve for long periods of time they may feel both capable and willing of micromanaging their subordinates.

What stands out in this research is that agency structure does, at least sometimes, matter in influencing how agency personnel view their workplace. Not every structural attribute 
matters, but it does appear that when agency leaders hold fixed terms, rather than be subject to at-will dismissal, agency professionals trust their leaders more and have more pride in their organizations. If trust and pride in the organization is a primary concern, one can make a strong case for designing agencies in such a way as to insulate their leaders from removal by fixing their terms of office (without making those terms too long). On the other hand, if the leadership and management of chief executives is of paramount importance, one could argue for an institutional design that makes agency leaders more responsive to elected officials (see Lewis, 2004).

Future research could examine the effect of insulating structural characteristics in other states, rather than only two. Other attributes that could affect political influence and bureaucratic autonomy could also be examined. These could include partisan balancing requirements for agency boards and commissions, occupational or professional background mandates for agency leaders, and provisions for legislative or executive review of agency orders. 


\section{REFERENCES}

Blau, P. M. (1973). The Organization of Academic Work. New York: John Wiley.

Blau, P., \& Schoenherr, R. (1971). The Structure of Organizations. New York: Basic Books.

Boyne, G. A. (2002). Public and private management: What's the difference? Journal of Management Studies, 39(1), 97-122.

Bozeman, B., \& Anderson, D.M. (2014). Public policy and the origins of bureaucratic red tape: Implications of the Stanford yacht scandal. Administration \& Society, 48(6), 736-759.

Bozeman, B., \& Rainey, H.G. (1998). Organizational rules and "bureaucratic personality." American Journal of Political Science, 42(1), 163-189.

Bressman, L.S., \& Thompson, R.B. (2010). The future of agency independence. Vanderbilt Law Review, 63, iii.

Brewer, G.A., \& Selden, S.C. (2000). Why elephants gallop: Assessing and predicting organizational performance in federal agencies. Journal of Public Administration Research and Theory, 20(1), 685-712.

Carpenter, D. (2010). Reputation and Power: Organizational Image and Pharmaceutical Regulation at the FDA. Princeton: Princeton University Press.

Carpenter, D. P., \& Krause, G. A. (2012). Reputation and Public Administration. Public Administration Review, 72(1), 26-32.

Carpenter, D., \& Moss, D. (eds). (2014). Preventing Regulatory Capture: Special Interest Influence and How to Limit It. New York: Cambridge University Press.

Cohen. H. (1970). Bureaucratic flexibility: Some comments on Robert Merton's 'Bureaucratic structure and personality.' The British Journal of Sociology, 21(4), 390-399.

Datla, K., \& Revesz, R. L. (2013). Deconstructing independent agencies (and executive agencies). Cornell Law Review, 98(4), 769-844.

Devins, B., \& Lewis, D. E. (2008). Not-so independent agencies: Party polarization and the limits of institutional design. Boston University Law Review, 88, 459-498.

Feeney, M. K. (2012). Organizational red tape: A measurement experiment. Journal of Public

Georgia State Merit System of Personnel Administration. (1996, August 30). GeorgiaGain implementation/merit system reform: Revised memorandum No. 1. (Available from Georgia Merit System) 
Hall, R. H. (1991). Organizations: Structures, Processes, and Outcomes, $5^{\text {th }}$ Edition. New Jersey: Prentice Hall.

Horn, M. J., \& Shepsle, K.A. (1989). Commentary on "Administrative arrangements and the political control of agencies": Administrative process and organizational form as legislative responses to agency costs. Virginia Law Review, 499-508.

Klingner, D. E. (2006). Societal values and civil service systems in the United States. In. J.E. Kellough and L.G. Nigro (eds.), Civil Service Reform in the States: Personnel Policy and Politics at the Subnational Level (11-32). Albany, New York: State University of New York Press.

Knott, J. H., \& Miller, G. J. (1987). Reforming bureaucracy: The politics of institutional choice. Englewood Cliffs, New Jersey: Prentice Hall.

Landau, M. (1969). Redundancy, rationality, and the problem of duplication and overlap. Public Administration Review, 29(4), 346-358.

Lewis, D. E. (2003). Presidents and the Politics of Agency Design: Political Insulation in the United States Government Bureaucracy, 1946-1997. Stanford, CA: Stanford University Press.

Lewis, D. E. (2004). “The Adverse Consequences of the Politics of Agency Design for Presidential Management in the United States: The Relative Durability of Insulated Agencies.” British Journal of Political Science 34: 377-404).

Lewis, D. E. (2007). Testing Pendleton's Premise: Do Political Appointees Make Worse Bureaucrats? Journal of Politics 69(4), 1073-1088.

Macey, J. R. (1992). Organizational design and political control of administrative agencies. Journal of Law, Economics, \& Organization, 8(1), 93-110.

Mansfield, R. (1973). Bureaucracy and centralization: An examination of organizational structure. Administrative Science Quarterly, 18(4), 77-88.

Marx, F. M. (ed). (1946). Elements of Public Administration. Prentice-Hall.

McCubbins, M. D., Noll, R. G., \& Weingast, B. R. (1987). Administrative Procedures as Instruments of Political Control. Journal of Law, Economics \& Organization, 3(2), 243277.

Merton, R. K. (1940). Bureaucratic structure and personality. Social Forces, 18(4), 560-568.

Meier, K. J., \& Krause, G. A. (2003). The scientific study of bureaucracy: An overview. Politics, Policy, and Organizations: Frontiers in the Scientific Study of Bureaucracy, 119. 
Miller, G. J., \& Whitford, A. B. (2016). Above Politics: Bureaucratic Discretion and Credible Commitment. Cambridge: Cambridge University Press.

Pandey, S. K., Coursey, D. H., \& Moynihan, D. P. (2007). Organizational effectiveness and bureaucratic red tape: A multimethod study. Public Performance \& Management Review, 30(3), 398-425. DOI: 10.2753/PMR1530-3576300305

Pandey, S. K., \& Moynihan, D.P. (2006). Bureaucratic red tape and organizational performance: Testing the moderating role of culture and political support. In. George A. Boyne, Kenneth J. Meier, Laurence J. O'Toole Jr., and Richard M. Walker (Eds), Public Service Performance. Cambridge, England, Cambridge University Press.

Pandey, S.K., \& Welch, E. W. (2005). Beyond stereotypes: A multistage model of managerial perception of red tape. Administration \& Society, 37(5), 542-575.

Potoski, M., \& Woods, N. D. (2001). Designing State Clean Air Agencies: Administrative Procedures and Bureaucratic Autonomy. Journal of Public Administration Research \& Theory, 11(2), 203-221.

Selin, J. L. (2015). What Makes an Agency Independent? American Journal of Political Science, 59(4), 971-987.

West, J. P. (2002). Georgia on the mind of radical civil service reformers. Review of Public Personnel Administration, 22(2), 79-93. 


\section{Table 1}

Descriptive Statistics

\begin{tabular}{|l|r|r|r|}
\hline & \multicolumn{1}{|c|}{ Mean } & \multicolumn{1}{c|}{$\begin{array}{c}\text { Std. Deviation } \\
\text { Statistic }\end{array}$} & $\begin{array}{c}\text { N } \\
\text { Statistic }\end{array}$ \\
\hline Age & 49.4427 & 8.91304 & 1204 \\
\hline Female & .4545 & .49813 & 1208 \\
\hline FTE & 3525.7147 & 5703.10303 & 1125 \\
\hline Georgia & .5487 & .49794 & 791 \\
\hline Commission & .4313 & .49559 & 742 \\
\hline FixedTerms & .5709 & .49527 & 783 \\
\hline Independent & .7487 & .43403 & 780 \\
\hline TermLength & 2.6347 & 2.58154 & 783 \\
\hline Valid N (listwise) & & & 689 \\
\hline
\end{tabular}


Table 2

\begin{tabular}{|c|c|c|c|}
\hline Variables & $\begin{array}{c}\text { Trust } \\
\text { Coefficients } \\
\text { (t-ratios) }\end{array}$ & $\begin{array}{c}\text { Pride } \\
\text { Coefficients } \\
\text { (t-ratios) }\end{array}$ & $\begin{array}{c}\text { High Ethical } \\
\text { Standards } \\
\text { Coefficients } \\
\text { (t-ratios) }\end{array}$ \\
\hline \multirow[t]{2}{*}{ (Constant) } & 2.233 & 2.479 & 2.560 \\
\hline & (8.072) & (10.711) & $(9.805)$ \\
\hline \multirow[t]{2}{*}{ Female } & 0.002 & 0.121 & 0.096 \\
\hline & $(0.028)$ & (1.949) & (1.369) \\
\hline \multirow[t]{2}{*}{ Age } & 0.005 & 0.011 & 0.008 \\
\hline & $(1.070)$ & (3.022) & (2.012) \\
\hline \multirow[t]{2}{*}{ FTE } & -2.482 E-005 & -1.489 E-005 & -1.374E-005 \\
\hline & $(-3.411)$ & $(-2.450)$ & $(-2.002)$ \\
\hline \multirow[t]{2}{*}{ Georgia } & 0.351 & 0.411 & 0.607 \\
\hline & (3.163) & (4.432) & (5.791) \\
\hline \multirow[t]{2}{*}{ Commission } & 0.220 & 0.121 & -0.100 \\
\hline & (1.205) & $(0.792)$ & $(-0.580)$ \\
\hline \multirow[t]{2}{*}{ Independent } & -0.091 & -0.042 & -0.173 \\
\hline & $(-0.747)$ & $(-0.409)$ & $(-1.492)$ \\
\hline \multirow[t]{2}{*}{ Fixed Terms } & 0.512 & 0.292 & -0.032 \\
\hline & (3.302) & (2.251) & $(-0.216)$ \\
\hline \multirow[t]{2}{*}{ Term Length } & -0.083 & -0.080 & -0.007 \\
\hline & $(-2.486)$ & $(-2.861)$ & $(-0.229)$ \\
\hline Adj. R-Square & 0.078 & 0.071 & 0.095 \\
\hline F-Statistics & 8.183 & 7.514 & 10.009 \\
\hline
\end{tabular}




\section{Table 3}

\begin{tabular}{|c|c|c|c|}
\hline Variables & $\begin{array}{c}\text { Employees' Fear of } \\
\text { Risk } \\
\text { Coefficients } \\
\text { (t-ratios) }\end{array}$ & $\begin{array}{c}\text { Managers' Fear of } \\
\text { Risk } \\
\text { Coefficients } \\
\text { (t-ratios) }\end{array}$ & $\begin{array}{c}\text { Risk Culture } \\
\text { Coefficients } \\
\text { (t-ratios) }\end{array}$ \\
\hline \multirow[t]{2}{*}{ (Constant) } & 3.285 & 3.116 & 6.330 \\
\hline & $(14.357)$ & $(12.376)$ & $(16.325)$ \\
\hline \multirow[t]{2}{*}{ Female } & -0.137 & -0.114 & -0.243 \\
\hline & $(-2.247)$ & $(-1.692)$ & $(-2.341)$ \\
\hline \multirow[t]{2}{*}{ Age } & -0.007 & -0.008 & -0.015 \\
\hline & $(-2.083)$ & $(-2.035)$ & $(-2.434)$ \\
\hline \multirow[t]{2}{*}{ FTE } & 3.747 E-006 & $2.226 \mathrm{E}-006$ & 7.146 E-006 \\
\hline & $(0.624)$ & $(0.336)$ & $(0.702)$ \\
\hline \multirow[t]{2}{*}{ Georgia } & -0.256 & -0.172 & -0.419 \\
\hline & $(-2.798)$ & $(-1.706)$ & $(-2.704)$ \\
\hline \multirow[t]{2}{*}{ Commission } & -0.018 & -0.459 & -0.468 \\
\hline & $(-0.119)$ & $(-2.766)$ & $(-1.837)$ \\
\hline \multirow[t]{2}{*}{ Independent } & 0.077 & 0.074 & 0.174 \\
\hline & $(0.759)$ & $(0.664)$ & $(1.011)$ \\
\hline \multirow[t]{2}{*}{ Fixed Terms } & -0.297 & -0.193 & -0.521 \\
\hline & $(-2.324)$ & $(-1.368)$ & $(-2.399)$ \\
\hline \multirow[t]{2}{*}{ Term Length } & 0.057 & 0.082 & 0.145 \\
\hline & (2.067) & $(2.690)$ & (3.096) \\
\hline Adj. R-Square & 0.030 & 0.060 & 0.068 \\
\hline F-Statistics & 3.597 & 6.421 & 7.103 \\
\hline
\end{tabular}

